\title{
Reaction of Onion Varieties to Stemphylium Blight (Stemphylium vesicarium)
}

\author{
Bhavya Mishra* and R.P. Singh \\ Department of Plant Pathology, College of Agriculture, G.B. Pant University of Agriculture \& \\ Technology,Pantnagar-263145, Uttarakhand, India \\ *Corresponding author
}

\begin{tabular}{|l|}
\hline Ke y w o r d s \\
Onion varieties, \\
Stemphylium \\
blight, Tarai region, \\
Bhima Shweta \\
\hline Article Info \\
\hline $\begin{array}{l}\text { Accepted: } \\
15 \text { March } 2019 \\
\text { Available Online: } \\
10 \text { April } 2019\end{array}$ \\
\hline
\end{tabular}

\section{Keywords}

Onion varieties Stemphylium blight, Tarai region,

Accepted: Available On April 2019

\section{A B S T R A C T}

Twenty one onion varieties were tested during 2017-18 at Pantnagar, Uttarakhand for evaluating their resistance levels against Stemphylium blight disease of onion caused by Stemphylium vesicarium (Wallr) Simmons under field and glasshouse conditions. The disease has emerged as a serious problem to onion growers all across the country including the tarai region of Uttarakhand. Disease occurred by natural infection in field while artificial inoculation was carried out in glasshouse. Disease severity was recorded when the typical disease symptoms had developed in field and 10 days after inoculation in glasshouse. Disease rating was done based on 0-5 rating scale and percent disease index was calculated. None of the 21 varieties screened was free from the disease. However, there were significant variations among the varieties under study. Results revealed that variety Bhima Shweta exhibited the least PDI among all the tested cultivars and displayed moderately resistant (MR) reaction to Stemphylium blight under glasshouse condition. Two other varieties viz. Arka Niketan and Bhima Shakti also showed less disease severity as compared to all other varieties, while still falling in the moderately susceptible category. The variety Poona Red Desi was found to be susceptible (S) to Stemphylium blight in field as well as glasshouse. All the tested varieties lied under the moderately susceptible (MS) category.

\section{Introduction}

Onion (Allium cepa L.) is one of the most commonly grown vegetable crops all over the world. It is an important commercial crop as it has high export value. India produces 23,262 ('000 MT) onion annually, with an average yield of 18.10 t/ha (DACFW, 2018). Despite being the second largest producer of onion in the world, our country falls behind many countries in terms of productivity. Among various reasons, unavailability of resistant varieties and prevalence of several diseases are the major constraints in onion production. The crop is attacked by many diseases which cause yield losses as well as deteriorate the quality and export potential of the produce. Stemphylium blight is one such disease, which has emerged as a serious problem throughout the country since past few years, 
especially in Northern and Eastern India. It is caused by a fungal pathogen Stemphylium vesicarium (Wallr.) Simmons and is known to cause serious damage in the tropics (Gupta et al., 1994). Foliar losses of 80 to $90 \%$ have been reported, leading to poor bulb yield (Maude, 1990). Infections occurs on the transplanted seedlings at 3-4 leaf stage on radial leaves, starting from December or early January, reaching the maximum intensity during March. The disease causes premature defoliation and makes the crop more susceptible to secondary infections like storage rots caused by various pathogens, which deteriorate the bulb quality (Rao and Pavgi, 1975).

Various methods are suggested for the management of Stemphylium blight such as cultural practices, field sanitation, biocontrol and chemical control. Strategies like manipulation of cultural practices or the use of biological control are effective in long term but are not able to provide immediate rescue when the disease has started to appear, as these methods require time to establish in field.

Application of fungicides provides quick and ensured effectiveness and therefore chemical pesticides remain a preference for farmers over the other methods of management. But the constant use of chemicals not only deteriorates the environment and harms the ecosystem, but also leads to problems like development of resistance in the pathogen against a particular chemical or group of chemicals. Also, there have been increasing concerns about the probability of pesticide residue accumulation in the edible plant parts which makes the produce less desirable or unfit for consumption and export purposes. Host resistance is the safest and most efficient way of averting or managing any biotic or abiotic stress. Onion varieties resistant/tolerant to purple blotch, thrips and basal rot are available.

Much of the efforts in breeding onions for disease resistance have been targeted towards purple blotch, fusarium basal rot and viral diseases. But no such resistant or tolerant variety has yet been bred against Stemphylium blight. So, it is required to make efforts towards finding a potential source of resistance among the existing germplasm by screening them against the pathogen.

\section{Materials and Methods}

The experiment for screening the onion varieties was conducted at Vegetable Research Centre, G.B. Pant University of Agriculture and Technology (Pantnagar) and under glasshouse conditions, during rabi season in 2017-18. A total of 21 onion varieties were grown in field with randomized block design and three replications each.

Three rows of 1 meter each were planted in three blocks. The disease in field appeared naturally and the varieties were evaluated in the month of March when the disease intensity is reaching at its peak. The same varieties were also tested under glasshouse in completely randomized design, also with three replications.

$0 \quad$ No disease symptom

1 A few spots towards tip covering 10 percent leaf area

2 Several purplish brown patches covering upto 20 percent of leaf area

3 Several patches with paler outer zone covering upto 40 percent leaf area

4 Leaf streaks covering upto 75 percent leaf area or breaking of the leaves from center

5 Complete drying of the leaves or breaking of leaves from center 
Two month old seedlings were transplanted in pots and were maintained under optimum growing conditions. 1 month after transplanting, the plants were artificially inoculated through spraying with a spore suspension of Stemphylium vesicarium having concentration $5 \times 10^{4}$ conidia $\mathrm{ml}^{-1}$. Then the disease rating was done 10 days after inoculation when the symptoms were clearly expressed. Disease ratings were given on the following 0-5 scale (Sharma, 1986).

The formula given by Wheeler (1969) was used to calculate the per cent disease index (PDI):

PDI for severity $=$

Sum of all disease ratings X 100

Total number of leaves $\mathrm{X}$ maximum rating value

The varieties were further placed in different categories based on their resistance or susceptibility reaction according to scoring as described in Table 1.

\section{Results and Discussion}

The data on disease severity showing the relative reaction of different onion varieties against Stemphylum blight under field and glasshouse conditions are presented in Table 2. None of the 21 varieties screened against Stemphylium blight was completely free from the disease. It was also found that none of the tested Allium серa varieties has resistance reaction against the disease. Very limited information is available regarding pest resistance in the existing onion cultivars in India. The sources of resistance may reside in the wild onion germplasms. It has been reported by Pathak et al., (2001) that five lines of Welsh onion (Allium fistulosum) exhibited complete to moderate resistance to $S$. vesicarium, but transfer of that resistance into common onion using conventional plant breeding is not that successful. They also tested 106 onion germplasm and all of them were found susceptible to this disease. This indicates the difficulty in breeding onion varieties for disease resistance. While studying the prevalence and incidence of Stemphylium blight of onion, Jakhar et al., (1994) have recorded higher disease incidence on seed crop of onion cultivar Hisar-2 than to the bulb crop of Hisar-2 and Pusa Red. Behera et al.,(2013) reported that out of 22 varieties screened under late kharif season, only two (VG-18, VG-19) were moderately resistant and remaining 17 were moderately susceptible to Stemphylium blight in 2010 . Not much work has been done regarding screening of onion varieties and germplasm against Stemphylium blight. Most of the studies related to this disease are from garlic (Ureba et al., 1999; Srivastava et al., 2005; Mishra et al., 2013). In the present investigation, Bhima Shweta exhibited the least disease severity in both glasshouse and field conditions and was found to be moderately resistant under glasshouse conditions.

Table.1 Scale for categorizing the varieties against Stemphylium blight of onion

\begin{tabular}{|c|c|l|}
\hline Score & Disease Severity $(\boldsymbol{\%})$ & Disease reaction \\
\hline $\mathbf{0}$ & $<5$ & Immune (I) \\
\hline $\mathbf{1}$ & $6-10$ & Resistant (R) \\
\hline $\mathbf{2}$ & $11-20$ & Moderately Resistant (MR) \\
\hline $\mathbf{3}$ & $21-40$ & Moderately Susceptible (MS) \\
\hline $\mathbf{4}$ & $41-60$ & Susceptible (S) \\
\hline $\mathbf{5}$ & $>60$ & Highly Susceptible (HS) \\
\hline
\end{tabular}


Table.2 Mean disease severity of Stemphylium blight of onion varieties tested under natural field condition and glasshouse conditions

\begin{tabular}{|c|c|c|c|c|c|}
\hline \multirow[t]{2}{*}{ S.No. } & \multirow[t]{2}{*}{ Varieties } & \multicolumn{2}{|c|}{ Field $^{\#}$} & \multicolumn{2}{|c|}{ Glasshouse } \\
\hline & & PDI $(\%)^{*}$ & Reaction & PDI $(\%)^{*}$ & Reaction \\
\hline 1. & N 53 & 37.00 & MS & 35.50 & MS \\
\hline 2. & Poona Red Desi & 42.36 & $\mathrm{~S}$ & 40.50 & $\mathrm{~S}$ \\
\hline 3. & Bhima Shakti & 26.79 & MS & 26.93 & MS \\
\hline 4. & Bhima Shubhra & 37.00 & MS & 33.00 & MS \\
\hline 5. & Bhima Shweta & 21.72 & MS & 20.50 & MR \\
\hline 6. & Bhima Dark Red & 29.50 & MS & 27.17 & MS \\
\hline 7. & Bhima Red & 32.00 & MS & 35.50 & MS \\
\hline 8. & Bhima Safed & 28.07 & MS & 26.21 & MS \\
\hline 9. & Bhima Kiran & 39.50 & MS & 34.79 & MS \\
\hline 10. & Bhima Super & 35.50 & MS & 32.50 & MS \\
\hline 11. & NHRDF Red 2 (L358) & 29.50 & MS & 28.00 & MS \\
\hline 12. & NHRDF Red 4 (L744) & 30.93 & MS & 29.07 & MS \\
\hline 13. & NHRDF Red 3 (L652) & 28.07 & MS & 29.07 & MS \\
\hline 14. & Agrifound Dark Red & 32.83 & MS & 30.50 & MS \\
\hline 15. & Agrifound Light Red & 30.93 & MS & 29.07 & MS \\
\hline 16. & Arka Niketan & 25.21 & MS & 23.36 & MS \\
\hline 17. & Arka Kalyan & 37.00 & MS & 33.00 & MS \\
\hline 18. & Arka Kirtiman & 28.07 & MS & 26.21 & MS \\
\hline 19. & Arka Lalima & 29.50 & MS & 25.50 & MS \\
\hline 20. & L28 & 27.00 & MS & 28.00 & MS \\
\hline 21. & Bhima Raj & 33.79 & MS & 31.93 & MS \\
\hline \multicolumn{6}{|l|}{22.} \\
\hline & $\mathrm{SE}(\mathrm{m}) \pm$ & 0.037 & & 1.323 & \\
\hline & C.D. & 0.107 & & 3.789 & \\
\hline
\end{tabular}

*all values are mean of 3 replications

\# RBD with angular transformation

Fig.1 Varieties showing Stemphylium blight under field conditions

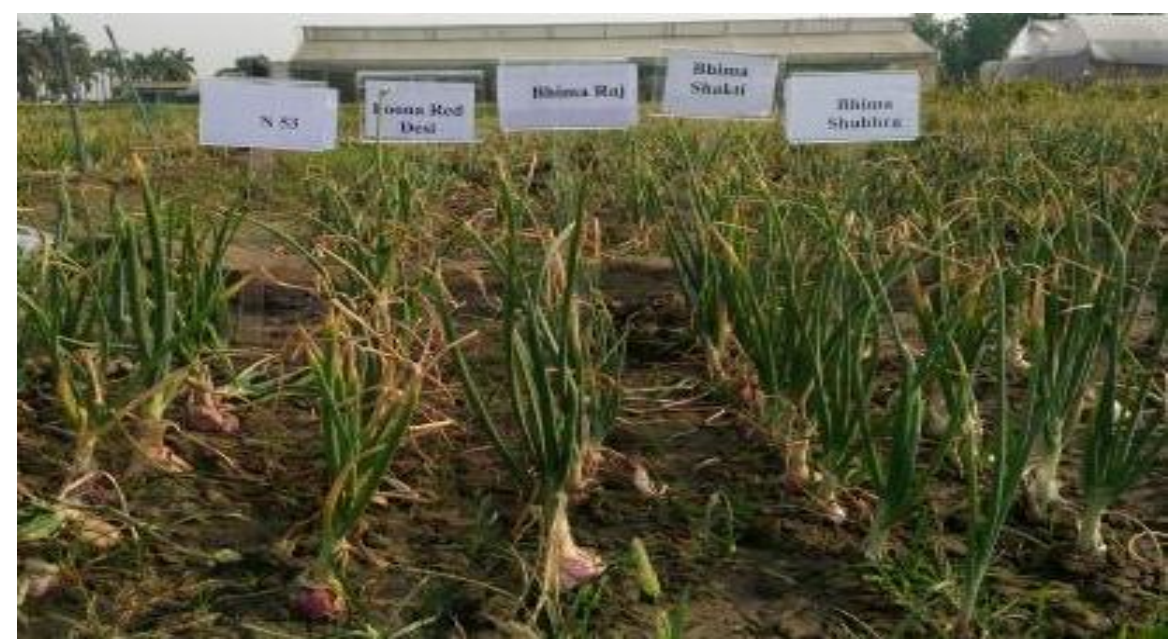


All the screened varieties were found to fall under moderately susceptible category, showing that none of the variety was completely free form the disease. However, along with Bhima Shweta, Arka Niketan, Bhima Shakti and L28 were also found to have comparatively lesser disease severity. Poona Red Desi showed susceptible reaction by having the highest disease severity under field as well as glasshouse conditions (Fig. 1). Similar results were also reported by Behera et al., (2013), who also found that L-28 and Arka Niketan were having lesser disease intensity as compared to other varieties.

Thus, Bhima Shweta, Arka Niketan, Bhima Shakti and L28 varieties can be chosen by the growers of tarai region of Uttarakhand. These varieties, in combination with effective biological and chemical management options may reduce the disease severity to a level that prevents economic losses. However, multilocation testing of various varieties and germplasms is required to find out suitable varieties that can be recommended to farmer so as to minimize the crop losses. Use of host resistance would be the most efficient way to manage diseases. However, no strong source of resistance has been identified in common onion, which calls up for an effort to screen more and more germplasms from not only the same species but also from wild relatives of the crop and develop a suitable method to identify and transfer that resistance trait to high yielding varieties.

\section{References}

Behera, S., Santra, P., Chattopadhyay, S., Das, S. and Maity, T.K. 2013. Variation in onion varieties for reaction to natural infection of Alternaria porri (ellis) ciff. and Stemphylium vesicarium (Wallr.). The Bioscan. 8(3): 759-761.

DACFW. 2018. Department of Agriculture Cooperation and Farmers Welfare. Area and Production of Horticulture Crops All India 2017-18. http://agricoop.nic.in/sites/default/files/ 2017-18-\%28Final\%29_updt.pdf.

Gupta, R.P., Srivastava, K.J. and Pandey, U.B.1994. Diseases and insect pests of onion in India. Acta Horticulturae 358:265-270.

Jakhar, S. S., Duhan, J. C. and Suhag, L. S. 1994. Prevalence and incidence of Stemphylium blight of onion and its management through cultural practices. Crop Res. (Hissar). 8 (3): 562-564.

Maude, R.B.1990. Leaf diseases of onions. In: Onion and Allied crops, Vol II, eds. H.D. Rabinowitch and J.L. Brewster. Boca Raton: CRC Press. pp. 173-189.

Mishra, R.K., Prasad, K., Pandey, S. and Gupta, R P. 2013. Evaluation of Garlic Accessions for Growth, Yield, Quality and Resistance to Stemphylium Blight Disease in Northern India. Vegetos. 26(2): 291-296

Mishra, R.K., Verma, A., Singh, S., and Gupta, R.P., 2009. Screening of garlic lines against purple blotch and stemphylium blight. Pest Management in Horticultural Ecosystems 15 (2): 138-140.

Pathak, S.S., Black, S.J., Cherng, T.C., and Ko, S.S., 2001. Breeding onions for stemphylium leaf blight resistance. Proc. II IS Edible Alliaceae Acta Horticulturae 555: 77-81.

Rao, N. N. R. and Pavgi, M. S. 1975. Stemphylium blight of onion. Mycopathologia. 56 (2): 113-118.

Sharma, S. R. 1986. Effect of fungicidal on purple blotch and bulb yield of onion. Indian Phytopathology. 39: 78-82.

Srivastava, K. J., Tiwari, B. K., Sharma, R. C. and Chauhan, K. P. S. 2005. Evaluation of different advanced lines against Stemphylium blight, purple blotch and thrips insect pests of garlic. News letter NHRDF. 25 (1): 10-12. 
Ureba, B.M.J., Prados-Ligero, A.M. and Melero-Vara, J.M. 1999. Aetiology of leaf spot of garlic and onion caused by Stemphylium vesicarium in Spain. Plant
Pathology. 48:139-145.

Wheeler, B. E. 1969. An Introduction to Plant Diseases. John Wiley and Sons Ltd, London, UK. pp 43-46.

\section{How to cite this article:}

Bhavya Mishra and Singh, R.P. 2019. Reaction of Onion Varieties to Stemphylium Blight (Stemphylium vesicarium). Int.J.Curr.Microbiol.App.Sci. 8(04): 1875-1880.

doi: https://doi.org/10.20546/ijcmas.2019.804.219 